\title{
Flavonoids and their aromatic derivatives in Piper betle powder promote in vitro methane mitigation in a variety of diets
}

\author{
Flavonóides e os seus derivados aromáticos no pó de Piper betle promovem \\ a mitigação in vitro do metano em diversas dietas
}

\author{
Rayudika Aprilia Patindra Purba1 (D), Siwaporn Paengkoum² (D), \\ Chalermpon Yuangklang 3 (D), Pramote Paengkoum ${ }^{1 *} \mathbb{D}$
}

\begin{abstract}
'Suranaree University of Technology, School of Animal Technology and Innovation, Nakhon Ratchasima, Thailand ${ }^{2}$ Nakhon Ratchasima Rajabhat University, Program in Agriculture, Nakhon Ratchasima, Thailand

${ }^{3}$ Rajamangala University of Technology-Isan University, Department of Agricultural Technology and Environment, Nakhon Ratchasima, Thailand *Corresponding author: pramote@sut.ac.th

Received in May 9, 2020 and approved in June 9, 2020
\end{abstract}

\begin{abstract}
At present, there is little information regarding whether supplementation with Piper betle powder (PBP) and sunflower oil (SFO) has a synergistic effect on lowering methane emissions without negatively impacting ruminal fermentation. This study investigated the effects of PBP, supplemented either with or without SFO, on biogas release, fermentation end-products, and microorganisms in the rumen of lactating goats. The treatments were run in a completely randomized $3 \times 5$ factorial arrangement, whereby 0,15 , and $30 \mathrm{mg}$ SFO were combined with $0,15,30,45$, and 60 mg PBP on a dry matter basis. The outcomes were assessed in vitro. PBP was obtained from the perennial plant Piper betle L., which is an abundant source of flavonoids and their aromatic derivatives. SFO, which reduces dietary methane emissions, was supplemented to confirm whether it interacted with other nutrients in the ruminant diet. SFO $\times$ PBP significantly $(p<0.05)$ decreased methane production, enhanced total volatile fatty acid concentrations, and decreased the number of rumen protozoa. We found that 15-30 mg, but not 45-60 mg, PBP combined with 0, 15, and $30 \mathrm{mg}$ SFO increased $(p<0.05)$ total gas production (including $\mathrm{CO}_{2}$ ) from fermentation. However, our results suggested that at least $45 \mathrm{mg}$ PBP, either alone or combined with SFO, was required to reduce ammonia- $\mathrm{N}(\mathrm{p}<0.05)$. Not all treatments affected rumen $\mathrm{pH}$. In conclusion, supplementing PBP $(<$ $30 \mathrm{mg}$ ), either alone or combined with SFO, has a suppressing effect on methane production while preserving an optimum rate of rumen fermentation.
\end{abstract}

Index terms: Environment; feed utilization; fermentation; methane reduction potential; polyphenols.

\begin{abstract}
RESUMO
Atualmente, há pouca informação sobre se a suplementação com Piper betle em pó (PBP) e óleo de girassol (SFO) tem um efeito sinérgico na redução das emissões de metano sem impacto negativo na fermentação ruminal. Este estudo investigou os efeitos da PBP, complementada com ou sem SFO, na liberação de biogás, produtos finais de fermentação e microrganismos do rúmen de cabras lactantes. Os tratamentos foram realizados em um arranjo fatorial completamente randomizado de $3 \times 5$, em que 0 , 15 e $30 \mathrm{mg}$ de SFO foram combinados com 0, 15, 30, 45 e $60 \mathrm{mg}$ de PBP em base de matéria seca. Os resultados foram avaliados in vitro. PBP foi obtida da planta perene Piper betle L., que é uma fonte abundante de flavonóides e seus derivados aromáticos. SFO, que reduz as emissões de metano na dieta, foi complementado para confirmar se interagia com outros nutritivos na dieta ruminante. A SFO $\times$ PBP diminuiu significativamente $(p<0,05)$ a produção de metano, aumentou as concentrações totais voláteis de ácidos graxos e diminuiu o número de protozoários de rúmen. Observou-se que 15-30 mg, e não 45-60 mg, PBP combinado com 0,15 , e 30 mg SFO aumentou $(p<0,05)$ a produção total de gás (incluindo $\mathrm{CO}_{2}$ ) a partir da fermentação. Contudo, os nossos resultados sugeriram que pelo menos $45 \mathrm{mg}$ de $\mathrm{PBP}$, isoladamente ou em combinação com SFO, é necessário para reduzir a amonia- $\mathrm{N}(\mathrm{p}<0,05)$. Nem todos os tratamentos afetaram o pH do rúmen. Em conclusão, complementar PBP $(<30 \mathrm{mg})$, sozinho ou combinado com SFO, tem um efeito de supressão na produção de metano, preservando ao mesmo tempo uma taxa ótima de fermentação do rúmen.
\end{abstract}

Termos para indexação: Ambiente; utilização dos alimentos; fermentação; potencial de redução do metano; polifenóis. 
PURBA, R. A. P. et al.

\section{INTRODUCTION}

Methane accounts for approximately $14 \%$ of greenhouse gases worldwide; this gas is emitted by ruminants under anaerobic conditions during ruminal fermentation (Sejian et al., 2011). As a result, there has been global interest in suppressing methane emissions without deleterious consequences on feed utilization (Yanza et al., 2018). Providing feed materials such as plant polyphenols and vegetable oils was expected to alter rumen inhabitants, resulting in improved rumen fermentation characteristics while reducing methane production since these supplementations have well-documented antimicrobial effects (Hook; Wright; McBride, 2010). Despite the considerable benefits of supplementing plant polyphenols and vegetable oils from a fermentation perspective, these rumen modifiers could modulate other nutrients in the ruminant diet (Lourenço et al., 2014; Elghandour et al., 2017; Purba; Paengkoum; Paengkoum, 2020). Notably, sunflower oil (SFO) has been suggested as a cost-effective way to alleviate methane production and provide concurrent nutrients such as fat inclusions (Vargas et al., 2017).

Piper betle L. is a part of the Piperaceae family and has been traditionally used raw as a natural antiseptic for humans, particularly for cleaning their mouths. P. betle leaves have protein, fat, carbohydrate, mineral, and other contents of about $3-3.5 \%, 0.4-1.0 \%, 0.5-6.10 \%, 2.3-3.3 \%$, and $86.5-93.5 \%$ respectively, of total nutrients in dry matter (Guha, 2006). Further, these leaves contain a host of polyphenols, especially flavonoids and essential oils (Purba; Paengkoum, 2019). Polyphenols originating from an extracted assay or a whole plant could be considered methane inhibitors as they have been shown to decrease enteric methane production (Jayanegara; Leiber; Kreuzer, 2012; Vasta; Daghio; Cappucci, 2019; Purba; Yuangklang; Paengkoum, 2020). However, there were adverse responses to feed digestion and ruminal fermentation when plant polyphenols were dosed at exceedingly high thresholds to obtain optimal methane mitigation (Patra; Yu, 2013; Vasta; Daghio; Cappucci, 2019). n detrimental cases, animals experienced toxicity resulting in impaired ruminant productivity and health (Waghorn; McNabb, 2003). In contrast, the above disastrous effects can be avoided at a lower threshold, but the methane mitigation would be decreased as well (Patra; Yu, 2015). A combination of a low amount of methane inhibitors, such nitrate and saponin, has been reported to decrease enteric methane production while maintaining feed digestion or substrate fermentation (Patra; Yu, 2013). At present, however, it is unknown whether supplementation with Piper betle powder (PBP) and SFO has a synergistic effect and can boost animal performance. We postulated that PBP could alter the ruminal fermentation pathway. Therefore, the objective of this study was to investigate the effects of PBP at five different doses, either with or without SFO, on biogas production, fermentation end-products, and microbial composition in rumen fluids from lactating goats, as estimated by in vitro techniques.

\section{MATERIAL AND METHODS}

All experimental procedures were approved and carried out in accordance with the Rules of Animal Welfare and all research on animals was conducted according to the Institutional Committee on Animal Use (SUT 4/2558).

\section{Animal, feed and Piper betle L. powder}

Four multiparous Saanen goats, Capra aegagrus hircus, ( $43 \pm 1.29 \mathrm{~kg}$ body weight) were assigned as rumen inoculum donors. All goats received a total mixed ration (TMR) consisting of a 50:50 mix of Pangola hay (particle size $>4 \mathrm{~cm})$ and concentrate, and had free access to drinking water. The TMR was offered in two portions $(60 \%$ at $09: 00$ and $40 \%$ at 17:00) and this feed was dedicated as a basal substrate in the later in vitro incubation. The formulation and chemical analysis of the feed (substrate) are presented in Table 1 .

$P$. betle leaves were purchased from a local market in the Prachinburi area of east Thailand. Fresh biomass of leafy plant material was pooled, rinsed, and kept overnight at $4{ }^{\circ} \mathrm{C}$. The leaves were air-dried using an oven set at $40^{\circ} \mathrm{C}$ for 2 days, turned into a powder (hereafter referred to as $P$. betle powder, PBP), loaded in sealed plastic, and kept in a desiccator until used. Flavonoid and aromatic contents were extracted and assayed in water, methanol, and hexane. The quantification procedure was performed using a highperformance liquid chromatography machine with a diodearray detector (HPLC-DAD Agilent Technologies 1260 Infinity, USA and Canada) (Purba; Paengkoum, 2019). Briefly, $5 \mathrm{~g}$ of PBP were extracted using $20 \mathrm{~mL}$ solvents individually and then run in a Soxhlet apparatus for 3-4 hours. The extracts were finally filtered through 0.45 $\mu \mathrm{m}$ polyvinyl difluoride syringe filters and subsequently diluted with mobile phase solution (1:9, HPLC-grade acetonitrile: $1 \%$ acetic acid). We injected $20 \mu \mathrm{L}$ of diluted extract into the HPLC-DAD machine, in which the extract was set in a 10-mm flow cell with 100 loops of automatic sample injection and four solvent delivery system quaternary pumps. Separation was achieved using a reversed-phase Zorbax SB-C18 column ( $3.5 \mu \mathrm{m}$ particle size, i.d. $4.6 \times 250 \mathrm{~mm}$ ) (Agilent Technologies). A standard stock solution was prepared using commercial quercetin 
and eugenol (Sigma-Aldrich, St. Louis, MO). Data collection was performed using OpenLAB CDS v1.8.1 (Agilent Technologies). All measurements were performed in triplicate and chemical standards were included in each analytical run as appropriate (Table 1).

Table 1: Ingredient and chemical composition of substrate and Piper betle L. powder.

\begin{tabular}{ccc}
\hline Item & Substrate $^{\mathrm{a}}$ & $\begin{array}{c}\text { Piper betle } \mathrm{L} . \\
\text { powder }^{\mathrm{b}}\end{array}$ \\
\hline $\begin{array}{c}\text { Ingredient (g kg-1 DM) } \\
\text { Dehydrated Pangola hay }\end{array}$ & 500 & - \\
Cassava pulp & 220 & - \\
Rice bran & 50 & - \\
Molasses & 40 & - \\
Palm meal & 130 & - \\
Soybean meal & 40 & - \\
Urea & 9 & - \\
Sulphur & 1 & - \\
Mineral & & - \\
Premix & & - \\
Chemical composition & 2 & - \\
(g kg-1 DM) & & \\
Organic matter & 982.62 & 921.73 \\
Crude protein & 112.33 & 24.40 \\
Ether extract & 24.71 & 3.57 \\
Acid detergent fiber & 600.59 & 664.05 \\
Neutral detergent fiber & 694.65 & 793.88 \\
Catechin & 0 & 3.06 \\
Rutin & 0 & 1.28 \\
Quercetin & 0 & 39.59 \\
Apigenin & 0 & 4.72 \\
Myricetin & 0 & 0.48 \\
Kaempferol & 0 & 3.11 \\
Eugenol & 0 & 8.65 \\
Caryophyllene & 0 & 2.86 \\
\hline
\end{tabular}

${ }^{\mathrm{a}}$ Contained fatty acid $\left(\mathrm{g} \mathrm{kg}^{-1} \mathrm{DM}\right): 16: 0$ (5.12), 18:0 (0.26), 18:2n6 (4.95) and 18:3n-3 (0.07); ${ }^{b}$ Contained fatty acids (g kg-1 DM): 16:0 (0.62), 18:0 (0.13), cis-9 18:1 (0.35), and 18:2n-6 (0.48); 'Contained ( $\left.\mathrm{g} \mathrm{kg}^{-1}\right)$ : $\mathrm{NaCl}(600), \mathrm{P}(160), \mathrm{Ca}(240)$; ${ }^{\mathrm{d}}$ Vitamin A $\left(4,200.000\right.$ IU $\left.\mathrm{kg}^{-1}\right)$, vitamin $A_{3}\left(840,000 \mathrm{IU} \mathrm{kg}{ }^{-1}\right)$, vitamin $\mathrm{E}$ $\left(10,000 \mathrm{IU} \mathrm{kg}^{-1}\right)$, vitamin $\mathrm{K}_{3}\left(2 \mathrm{~g} \mathrm{~kg}^{-1}\right)$, vitamin $\mathrm{B}_{1}\left(2.4 \mathrm{~g} \mathrm{~kg}^{-1}\right)$, vitamin $\mathrm{B}_{2}\left(3.5 \mathrm{~g} \mathrm{~kg}^{-1}\right)$, vitamin $\mathrm{B}_{6}\left(1.8 \mathrm{~g} \mathrm{~kg}^{-1}\right)$, vitamin $\mathrm{B}_{12}\left(0.01 \mathrm{~g} \mathrm{~kg}^{-1}\right)$, vitamin $B_{5}\left(4.6 \mathrm{~g} \mathrm{~kg}^{-1}\right)$, vitamin $\mathrm{C}\left(12 \mathrm{~g} \mathrm{~kg}^{-1}\right)$, folic acid $\left(0.28 \mathrm{~g} \mathrm{~kg}^{-1}\right)$, vitamin $7^{5}\left(0.4 \mathrm{~g} \mathrm{~kg}^{-1}\right)$, coper $\left(12 \mathrm{~g} \mathrm{~kg}^{-1}\right)$, manganese $\left(40 \mathrm{~g} \mathrm{~kg}^{-1}\right)$, zinc $\left(3.2 \mathrm{~g} \mathrm{~kg}^{-1}\right)$, iron $\left(42 \mathrm{~g} \mathrm{~kg}^{-1}\right)$, iodine $\left(0.8 \mathrm{~g} \mathrm{~kg}^{-1}\right)$, cobalt $\left(0.8 \mathrm{~g} \mathrm{~kg}^{-1}\right)$, selenium $\left(0.35 \mathrm{~g} \mathrm{~kg}^{-1}\right)$.

\section{Treatments}

Treatments followed a $3 \times 5$ factorial arrangement in a completely randomized design, whereby three doses of SFO $(0,15$, and $30 \mathrm{mg})$ were combined with five doses of PBP $(0,15,30,45$, and $60 \mathrm{mg})$ on a dry matter (DM) basis. SFO composition (in $\mathrm{g} \mathrm{kg}^{-1}$ fatty acid) was as follows: 16:0 (51.07), 18:0 (27.36), cis-9 18:1 (355.43), 18:2n-6 (422.24), and 18:3n-3 (1.74). SFO and PBP were emulsified in a 1:99 $\mathrm{v} \mathrm{v}^{-1} 96 \%$ ethanol: aqueous solution, then decanted into a glass syringe. The glass syringe that contained $0 \mathrm{mg}$ of PBP and $0 \mathrm{mg}$ of SFO was designated as the control treatment. The PBP and SFO doses were selected based on prior studies and were considered both safe for the animals and practical for the farmers (Lourenço et al., 2014; Vargas et al., 2017; Purba; Paengkoum; Paengkoum, 2020).

\section{In vitro experiment}

After a 15-day adaptation period, rumen fluids were suctioned from the rumen using an oral lavage solution and a suction pump (CV-SF18, Hitachi, Tokyo, Japan) before morning feeding time (Tian et al., 2018). The $\mathrm{pH}$ of the rumen fluids were strictly checked to avoid contamination from goat saliva (Menke; Steingass, 1988). Rumen fluid was moved to the laboratory $\left(14^{\circ} 52^{\prime} 36^{\prime \prime} \mathrm{N}, 102^{\circ} 00^{\prime} 54^{\prime \prime} \mathrm{E}\right.$; elevation above $200 \mathrm{~m}$ ) in a pre-warmed thermal flask, then strained using a nylon membrane $(400 \mu \mathrm{m}$; Fisher Scientific S.L., Madrid, Spain) while bubbled with $\mathrm{CO}_{2}$. The artificial solution was prepared per an earlier protocol (Menke; Steingass, 1988) and mixed with strained rumen liquors (2:1, volume: volume) under continuous $\mathrm{CO}_{2}$ at $39^{\circ} \mathrm{C}$. Every hundred glass syringes containing the earlier SFO and PBP as treatment were combined with $500 \mathrm{mg}$ of basal substrate. For instance, the control treatment contained 500 $\mathrm{mg}$ of basal substrate, $0 \mathrm{mg}$ of SFO, and $0 \mathrm{mg}$ of PBP. We then added $30 \mathrm{~mL}$ of rumen mixture as a final preparation prior to incubation. Once the glass syringes were locked with 3-way stopcocks and capped by glass plungers, the glass syringes were subsequently shaken and placed in a water bath set at $39^{\circ} \mathrm{C}$. The incubation was run for $72 \mathrm{~h}$, including shaking once per hour. To get representative results, all incubations were completed in 10 replications over three runs on separate days and gas production was corrected with blanks (three glass syringes that only contained rumen mixture were included in each run).

\section{Sample analysis}

DM was prepared (\#950.02) and analyzed (\#925.04) from $2.0 \mathrm{~g}$ of grinded sample after drying 
PURBA, R. A. P. et al.

using a forced-air oven at $105^{\circ} \mathrm{C}$ for $4 \mathrm{~h}$ (AOAC, 2005). Organic matter $(\mathrm{OM})$ content was calculated as a hundred percent minus ash percentage, which was obtained after incineration in a muffle furnace at $550{ }^{\circ} \mathrm{C}$ for $5 \mathrm{~h}$ (\#942.05) (AOAC, 2005). Total $\mathrm{N}$ was measured using the Kjeldahl method and crude protein concentration was calculated as total $\mathrm{N} \times 6.25$ (\#984.13), (AOAC, 2005). Ether extract concentration was measured by extraction with petroleum ether (\#920.39) (AOAC, 2005) and fatty acid concentration was calculated from methylation using a gas chromatography machine (Agilent 7890A GC, Agilent Technologies) with external FAME standards (Supelco 37-Component FAME Mix, Supelco Inc., Bellefonte, PA) (Lourenço et al., 2014). Concentrations of acid detergent fiber and neutral detergent fiber were measured by sequential analysis without amylase (we used sodium sulfite instead) and expressed with residual ash included (Van Soest; Robertson; Lewis, 1991). The gross energy was determined using a bomb calorimeter with an $\mathrm{O}_{2}$ carrier (Parr 6200 bomb calorimeter, Parr Instruments Co., Moline, IL) according to the manufacturer's instructions. All measurements were performed in triplicate and chemical standards were included in each analytical run as appropriate (Table 1).

Gas production was read, recorded, and measured at $0,2,4,6,8,10,12,24,36,48$, and $72 \mathrm{~h}$ by adapting a prior gas pressure technique (Theodorou et al., 1994). To calculate the cumulative volume of gas production (Equaton 1), the numerical measurement was fitted to the model of Orskov and McDonald (1970) as:

$y=a+b\left(1-e^{(-c t)}\right)$

where a $\left(\mathrm{mL} \mathrm{g}^{-1} \mathrm{DM}\right)$ is the gas production from the soluble fraction, $b\left(\mathrm{~mL} \mathrm{~g}^{-1} \mathrm{DM}\right)$ is the gas production from the insoluble fraction, $\mathrm{c}\left(\mathrm{h}^{-1}\right)$ is the gas production rate constant for the insoluble fraction (b), $t(h)$ is the incubation time, $(\mathrm{a}+\mathrm{b})\left(\mathrm{mL} \mathrm{g}^{-1} \mathrm{DM}\right)$ is the potential extent of gas production, and $y\left(\mathrm{~mL} \mathrm{~g}^{-1} \mathrm{DM}\right)$ is the gas produced at time ' $\mathrm{t}$ '.

At 24 and $72 \mathrm{~h}, 10 \mathrm{~mL}$ of gas was transferred into a disposal syringe for directly injecting into the gas chromatography machine (Agilent 7890A, Agilent Technologies) to measure methane and carbon dioxide levels. To obtain the acceptable separation, internal standards were applied into the peak rate for methane (FIDI A, front signal, 0.900-0.999 $\mathrm{min}$ ) and carbon dioxide (TCD2 B, back signal, 0.924-0950 min). The methane, carbon dioxide, and cumulative gas production were expressed as $\mathrm{mL} / \mathrm{g}$ of OM disappeared after 24 and $72 \mathrm{~h}$ of incubation (Ribeiro Junior et al., 2014).

After $24 \mathrm{~h}$ of incubation, rumen fluids were then filtered through four layers of cheesecloth. Once the glass syringes were unplugged, $\mathrm{pH}$ was immediately measured using a pH meter (Oakton 700, Cole-Parmer, Vernon Hills, IL). Samples were divided into 2 portions; the first portion was centrifuged at $6,000 \times \mathrm{g}$ for $15 \mathrm{~min}$ at $4{ }^{\circ} \mathrm{C}$ and the supernatant was stored at $-20{ }^{\circ} \mathrm{C}$ before $\mathrm{NH}_{3}-\mathrm{N}$ analysis using the micro-Kjeldahl methods (Kjeltec 8100 , Hilleroed, Denmark) (AOAC, 2005) and volatile fatty acid (VFA) detection by gas chromatography (Agilent 6890 GC, Agilent Technologies) (Erwin; Marco; Emery, 1961). The second portion was fixed with $10 \%$ formalin solution in a sterilized $0.9 \%$ saline solution for calculating total bacteria, protozoa, and fungal zoospores using a Neubauer counting chamber. Subsequently, the fixed solution was diluted with autoclaved deionized water as a medium 100,10 , and 10 times and counted using $10 \times 40,10 \times 40$, and $10 \times 10$ ocular $\times$ objective for total bacteria, fungal zoospores, and protozoa, respectively (Galyean, 1989).

In vitro degradability was determined after 24 and $72 \mathrm{~h}$ of incubation following an earlier protocol (Tilley; Terry, 1963). The filtered contents were collected through pre-weighed Gooch crucibles and residual dry matter was calculated. The percent loss in weight was calculated and dedicated as the in vitro dry matter degradability. The dried feed sample and residue left from the above process was incinerated in a furnace at $550^{\circ} \mathrm{C}$ for $5 \mathrm{~h}$ for determination of the in vitro organic matter degradability.

\section{Statistical analysis}

The data were analyzed in a $3 \times 5$ factorial arrangement in a completely randomized design using the PROC GLM procedure in SAS 9.4. Since the data from the three consecutive runs of incubations were comparable, the data were averaged and analyzed using the one-way analysis of variance. Multiple comparisons among SFO supplementations, PBP treatments, and interactions were performed using Tukey's honestly significant difference test (Kaps; Lamberson, 2004). Differences among means at $\mathrm{p}<0.05$ were accepted as representing statistically significant differences.

\section{RESULTS AND DISCUSSION}

The PBP used in this study contained roughly $52.24 \mathrm{~g} / \mathrm{kg} \mathrm{DM}$ and $11.51 \mathrm{~g} / \mathrm{kg} \mathrm{DM}$ of secondary metabolites, which accounted for flavonoids and aromatic/ essential oils, respectively (Table 1). Among the present 
secondary metabolites, quercetin and eugenol were major compounds. In the present study, we tested whether these two active plant metabolites interacted with SFO supplementations to modulate rumen fermentation and its biogas production. All outcomes were expected to reduce methane production and enhance the fermentation endproduct. Therefore, we evaluated the effect of different levels of SFO supplementation with different doses of PBP.

\section{Ruminal biogas and degradability}

Increased PBP levels in different substrates $(0,15$, $30 \mathrm{mg}$ of SFO) did not show a reduction in gas production after $72 \mathrm{~h}$ of incubation (Figure 1). Adding PBP at 15-30 $\mathrm{mg}$, either with or without SFO, increased both total gas production (including $\mathrm{CO}_{2}$ ) from fermentation and organic matter degradability (Table 2). SFO did not affect those parameters. Exceedingly high doses of PBP (45-50 $\mathrm{mg}$ ) were shown to have an opposite effect. SFO $\times$ PBP significantly $(\mathrm{p}<0.05)$ affected methane production after 24 and $72 \mathrm{~h}$ of incubation. Methane production decreased when PBP was combined with $0 \mathrm{mg}$ of SFO (up to $37 \%$ ), $15 \mathrm{mg}$ of SFO (up to $20 \%$ ), and $30 \mathrm{mg}$ of SFO (up to $16 \%$ ).

The gas production trend of substrates treated by Piper betle L. powder (PBP). S1, control or no PBP content; S2, 15 mg PBP; S3, 30 mg PBP; S4, 45 mg PBP; and S5, $60 \mathrm{mg}$ PBP. (a) No SFO supplementation; (b) Low SFO, $15 \mathrm{mg}$; (c) High SFO, $30 \mathrm{mg}$. Data reported as leastsquares \pm standard error of mean $(\mathrm{N}=30)$.

It has been previously reported that gases such as hydrogen $\left(\mathrm{H}_{2}\right)$, methane $\left(\mathrm{CH}_{4}\right)$, and carbon dioxide $\left(\mathrm{CO}_{2}\right)$ are produced as a result of substrate fermentation in the rumen (Wolin; 1979). Carbohydrates, proteins, and lipids of substrates are degraded by rumen microorganisms and shifted into microbial cells. In the present study, the lack of SFO effect on total gas production (including $\mathrm{CO}_{2}$ ) from fermentation and degradability was consistent with a previous study by Vargas et al. (2017), who reported comparable results for estimated total gas production and degradability rate maintained in semi-continuous flow fermenters (RUSITEC) in rumen fluid from sheep. This notion was substantiated by the fact that increasing SFO supplementations in the substrate tended to maintain total gas production (including $\mathrm{CO}_{2}$ ). Thus, it appears that $\mathrm{SFO}$ is a relatively unfermentable nutrient source. However, in the present study, increasing PBP, which contained flavonoids and their aromatic derivatives, enhanced the fermentable organic degradability in substrate fermentation, resulting in a greater total gas production (including $\mathrm{CO}_{2}$ ). Notably, $\mathrm{PBP}$ is an abundant carbohydrate source (Table 1). It has been reported that plant polyphenols richer in flavonoids could be degraded in nutrient fermentation, especially by carbohydrate-degrading bacteria (McSweeney et al., 2001). Given this information, the presence of PBP has been shown to increase ruminal biogases whereby the degraded PBP made a predominant contribution to additional fermentable nutrient sources, such as carbohydrates (Orskov; McDonald, 1970). The carbohydrate content of the feed substrate was identical at the onset of each treatment in the present study; thus, the surge in ruminal biogases and degradability rates were
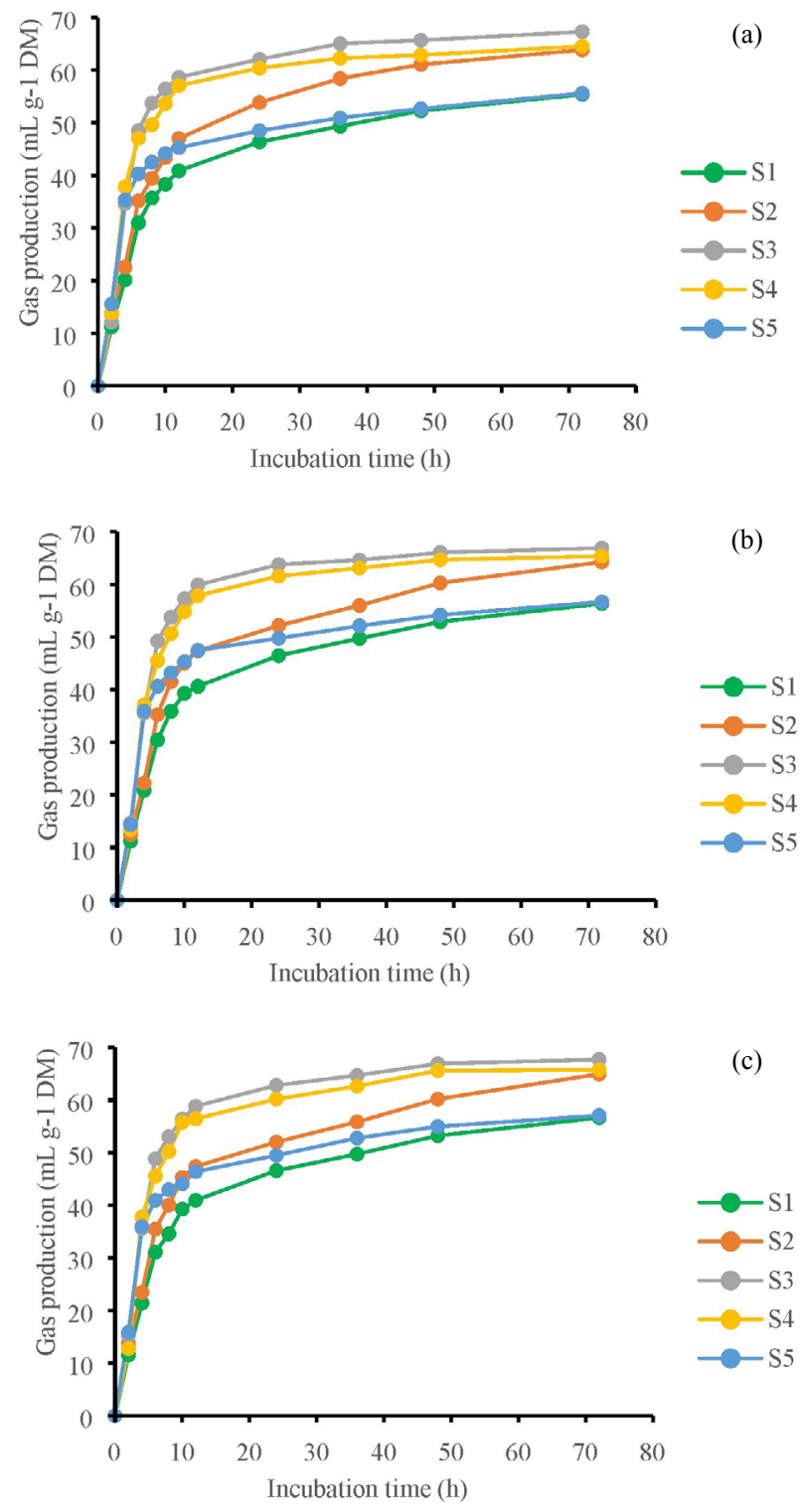

Figure 1: The trend of gas production for $72 \mathrm{~h}$ in a variety of diets. 
Table 2: Effect of treatments on biogas production and in vitro degradability at 24 and $72 \mathrm{~h}$ after incubation.

\begin{tabular}{|c|c|c|c|c|c|c|c|c|c|c|c|}
\hline \multirow[t]{2}{*}{$\mathrm{SFO}^{1}$} & \multirow[t]{2}{*}{$\mathrm{PBP}^{2}$} & \multicolumn{2}{|c|}{$\begin{array}{l}\text { Total gas } \\
\text { production } \\
\text { (mL g-1 OM) }\end{array}$} & \multicolumn{2}{|c|}{$\begin{array}{l}\mathrm{CO}_{2} \text { production } \\
\left(\mathrm{mL} \mathrm{g}^{-1} \mathrm{OM}\right)\end{array}$} & \multicolumn{2}{|c|}{$\begin{array}{c}\mathrm{CH}_{4} \text { production } \\
\left(\mathrm{mL} \mathrm{g}^{-1} \mathrm{OM}\right)\end{array}$} & \multicolumn{2}{|c|}{$\begin{array}{c}\text { In vitro dry } \\
\text { matter } \\
\text { degradability (\%) }\end{array}$} & \multicolumn{2}{|c|}{$\begin{array}{l}\text { In vitro organic } \\
\text { matter } \\
\text { degradability (\%) }\end{array}$} \\
\hline & & $24 \mathrm{~h}$ & $72 \mathrm{~h}$ & $24 \mathrm{~h}$ & $72 \mathrm{~h}$ & $24 \mathrm{~h}$ & $72 \mathrm{~h}$ & $24 \mathrm{~h}$ & $72 \mathrm{~h}$ & $24 \mathrm{~h}$ & $72 \mathrm{~h}$ \\
\hline \multirow{5}{*}{ No } & $\mathrm{S} 1^{3}$ & $85.83 e$ & $177.76 \mathrm{e}$ & $71.39 d$ & $140.67 e$ & 14.41ax & $36.64 a x$ & 55.76 & 63.01 & $54.01 d$ & $60.23 d$ \\
\hline & S2 & $99.65 c$ & $205.64 c$ & $87.72 b$ & $181.09 c$ & $11.89 \mathrm{bx}$ & $7 b x$ & 56.01 & 63.29 & $56.26 c$ & $62.61 c$ \\
\hline & S3 & $114.87 a$ & $226.62 a$ & $104.88 a$ & 207.31a & $9.95 c x$ & $18.64 c x$ & 56.27 & 62.86 & $64.15 a$ & $67.72 a$ \\
\hline & S4 & $111.75 b$ & $218.89 b$ & $102.18 a$ & $198.58 b$ & $9.52 c x$ & $19.67 c x$ & 56.22 & 62.91 & $59.07 b$ & $65.46 \mathrm{~b}$ \\
\hline & S5 & $9.76 \mathrm{~d}$ & $182.08 d$ & $80.29 c$ & $42 d$ & $c x$ & 19 & 56.26 & 62.97 & $55.07 d$ & $60.33 d$ \\
\hline \multirow{5}{*}{ Low } & 3 & $86.08 \mathrm{e}$ & $179.65 \mathrm{e}$ & $74.04 d$ & $153.29 \mathrm{e}$ & $b x$ & & 55.93 & & $54.04 d$ & $60.15 d$ \\
\hline & $\mathrm{sL}$ & $96.62 c$ & $203.35 c$ & $\mathrm{~b}$ & $180.70 c$ & 10.3 & 7by & 56.09 & 50 & $56.59 c$ & $62.04 c$ \\
\hline & S3 & a & 229. & 109 & & & & 56.33 & & 63.60a & $66.52 a$ \\
\hline & S4 & b & 222 & a & & & & 56.36 & & $7 b$ & $4.71 b$ \\
\hline & S5 & $19 d$ & 186. & $7 \mathrm{c}$ & $3 d$ & & cy & 55.96 & & 54. & $60.51 d$ \\
\hline \multirow{5}{*}{ High } & S1 & $86.24 \mathrm{e}$ & $180.34 \mathrm{e}$ & $75.89 d$ & $154.08 \mathrm{e}$ & 10. & $7 b x$ & 55.90 & r & $54.29 d$ & $60.23 d$ \\
\hline & S2 & $96.34 c$ & $204.20 c$ & $87.13 b$ & $182.93 c$ & $9.17 d y$ & $20.68 \mathrm{bz}$ & 55.88 & 63 & $56.51 c$ & $62.18 c$ \\
\hline & S3 & 116.30a & $228.76 a$ & 108.73a & $211.82 a$ & $7.53 e z$ & $16.26 \mathrm{dz}$ & 55.78 & 63.03 & $64.30 \mathrm{a}$ & $66.42 a$ \\
\hline & S4 & $111.43 b$ & $220.63 b$ & $103.72 a$ & $203.38 b$ & $7.66 \mathrm{ez}$ & $16.59 d z$ & 55.97 & 63.25 & $57.99 b$ & $63.23 \mathrm{~b}$ \\
\hline & S5 & $91.64 d$ & $186.38 d$ & $84.09 c$ & $169.56 d$ & $7.51 \mathrm{ez}$ & $16.27 \mathrm{dz}$ & 56.14 & 62.97 & $54.23 d$ & $60.38 d$ \\
\hline $\mathrm{SEM}^{4}$ & & 0.318 & 0.514 & 0.344 & 0.600 & 0.048 & .136 & 0.05 & 0.040 & 0.096 & 0.069 \\
\hline \multicolumn{12}{|l|}{ P-values } \\
\hline SFO & & 0.064 & 0.05/ & 0.051 & 0.056 & 0.038 & 0.025 & 0.620 & $0.98 /$ & 0.087 & 0.080 \\
\hline PBP & & 0.019 & 0.002 & 0.027 & 0.036 & 0.019 & 0.012 & 0.555 & 0.987 & 0.021 & 0.015 \\
\hline $\mathrm{SFO} \times \mathrm{PBP}$ & & 0.144 & 0.493 & 0.303 & 0.086 & 0.042 & 0.027 & 0.539 & 0.961 & 0.469 & 0.493 \\
\hline
\end{tabular}

${ }^{1}$ SFO, sunflower oil supplementation per incubation at no $(0 \mathrm{mg})$; low (15 mg); high (30 mg); ${ }^{2} \mathrm{PBP}$, Piper betle L. powder supplementation per incubation at S1 (0 mg); S2 (15 mg); S3 (30 mg); S4 (45 mg); S5 (60 mg); ${ }^{3}$ dedicated as control treatment (only substrate); ${ }^{4} \mathrm{SEM}$, standard error of mean. Within a parameter as column, means with different superscript $(a, b, c)$ differ at $p<0.05$ for the PBP effect in substrate; with different superscripts $(x, y, z)$ at $p<0.05$ for the SFO effect in substrate.

expected from modulated carbohydrates and other glucose fermentations degraded by rumen microorganisms during substrate incubation. However, exceedingly high levels of PBP (> 10\%) supplementation have shown an adverse effect that might increase toxicity for rumen inhabitants (Yanza et al., 2018).

Furthermore, the supplementation of SFO and PBP modulated ruminal fermentation and effectively reduced methane production. The extent of methane mitigation by SFO and PBP was equal to that reported by previous studies (Vargas et al., 2017; Yanza et al., 2018). This methane reduction might have occurred due to the flavonoids and essential oils of PBP. Previous references reported similar results that flavonoids and essential oils had a well-documented antimicrobial effect in rumen methanogenesis through interfering with the outer membrane of gram-positive bacteria (Patra; Saxena, 2010; Canova et al., 2015; Purba; Yuangklang; Paengkoum, 2020). This motion caused bacteria to lose their control over ion gradients, electron mobilization, phosphorylation cascades, protein translocation, and other enzymatic reactions (Ultee; Bennik; Moezelaar, 2002). In the present study, the combination of SFO and PBP tended to cause a reduction in $\mathrm{CH}_{4}$. To our knowledge, the present study is the first investigation of the effects of a combination of SFO and polyphenol on enteric methane production. However, a previous study combining SFO and microalgae could be assessed due to the polyphenolic properties ascertained in microalgae (Haoujar; Cacciola; Abrini, 2019). Schizochytrium microalgae and SFO 
appeared to alleviate ruminal methane production in rumen fluid of steers and goats (Elghandour et al., 2017). It is worth highlighting that the varied responses to SFO and microalgae inclusions in goat rumen were expected due to the type and dose of the basal diet and lipid inclusion (Hook; Wright; McBride, 2010). Our results elaborated that the combination of SFO and PBP attenuated bacteria activity in the rumen, especially the methanogen group, in which flavonoids of PBP may compete with SFO to possess the target sites through their hydrophobic interaction. Antimicrobial properties of flavonoids and oils have been observed to understand the efficacy of their activity against varied bacteria (Mandalari et al., 2007). This notion was substantiated by the fact that increasing SFO supplementations with PBP levels led to augmented rumen methanogenesis activity.

\section{Fermentation parameter}

There were significant interactions $(\mathrm{p}<0.05)$ between SFO and PBP for total VFA and the ratio of acetic to propionic acid and its acid fractions, except iso-acids (Table 3). Increased PBP levels in different substrates $(0$, $15,30 \mathrm{mg}$ of SFO) increased acetic acid without altering $\mathrm{pH}$. Supplementing at least $45 \mathrm{mg}$ of PBP, either alone or in combination with SFO, decreased ammonia-N $(\mathrm{p}<0.05)$.

It has been previously reported that adding SFO (ca. 2\% of total feed substrate) containing unsaturated fatty acids increased VFA concentration (Vargas et al., 2017). Furthermore, polyphenol utilization by adding doses of commercial quercetin and eugenol at 250-500 $\mathrm{mg} \mathrm{L}^{-1}$ has shown inconsistent results (Lourenço et al., 2014). Quercetin, but not eugenol, resulted in a greater concentration of VFA. Given those reports, the increased

Table 3: Effect of treatments on $\mathrm{pH}, \mathrm{NH}_{3}-\mathrm{N}$ and total volatile fatty acid (TVFA).

\begin{tabular}{|c|c|c|c|c|c|c|c|c|c|c|c|}
\hline $\mathrm{SFO}^{1}$ & $\mathrm{PBP}^{2}$ & $\mathrm{pH}$ & $\begin{array}{c}\mathrm{NH}_{3}-\mathrm{N} \\
(\mathrm{mg} \\
\left.(100 \mathrm{~mL})^{-1}\right) \\
\end{array}$ & $\begin{array}{c}\text { TVFA } \\
(\mathrm{mmol} \mathrm{L-1})\end{array}$ & $\begin{array}{l}\text { Acetic } \\
\text { acid } \\
\left(C_{2}\right)(\%)\end{array}$ & $\begin{array}{l}\text { Propionic } \\
\text { acid } \\
\text { (C3) (\%) }\end{array}$ & $\begin{array}{l}\text { Iso-butyric } \\
\text { acid (\%) }\end{array}$ & $\begin{array}{l}\text { Butyric } \\
\text { acid (\%) }\end{array}$ & $\begin{array}{c}\text { Iso-valeric } \\
\text { acid (\%) }\end{array}$ & $\begin{array}{l}\text { Valeric } \\
\text { acid (\%) }\end{array}$ & $\begin{array}{l}\text { Ratio } \\
C_{2}: C_{3}\end{array}$ \\
\hline \multirow{5}{*}{ No } & $\mathrm{S} 1^{3}$ & 6.92 & $17.43 a$ & $68.36 c x$ & $56.27 c$ & 19.60ax & 4.63 & $10.14 c$ & 4.95 & $4.41 a x$ & $2.87 c x$ \\
\hline & S2 & 6.83 & $17.69 a$ & $70.07 b x$ & $56.55 c$ & $19.63 a x$ & 4.19 & $11.26 c$ & 4.28 & $.09 \mathrm{bx}$ & $2.88 \mathrm{cx}$ \\
\hline & S3 & 6.83 & $17.86 a$ & $71.82 \mathrm{bx}$ & $58.89 \mathrm{~b}$ & 19.47ax & 2.35 & $12.39 b$ & 3.51 & $3.39 c x$ & $3.02 \mathrm{bx}$ \\
\hline & S4 & 6.83 & $18.02 a$ & 73.62by & $59.72 a$ & 18.46bx & 2.35 & $12.54 a$ & 3.53 & $3.40 c x$ & $3.24 a x$ \\
\hline & S5 & 6.83 & $16.24 \mathrm{~b}$ & 75.46ax & $54.34 c$ & $18.44 \mathrm{bx}$ & 3.79 & $12.69 a$ & 5.69 & $.05 a z$ & $2.95 \mathrm{bx}$ \\
\hline \multirow{5}{*}{ Low } & S1 & 6.83 & $17.46 a$ & 73.14by & $54.84 c$ & 20.67ay & 3.71 & $10.39 c$ & 5.55 & 4.84ay & $2.65 c y$ \\
\hline & S2 & 6.83 & $17.02 a$ & 78.11ay & $57.40 \mathrm{~b}$ & 20.61 ay & 2.45 & $12.22 \mathrm{~b}$ & 3.67 & 3.65by & $2.79 c x$ \\
\hline & S3 & 6.83 & $17.19 a$ & 78.50ay & $57.42 b$ & 20.34ay & 2.10 & $14.20 a$ & 3.16 & $2.78 c y$ & $2.82 \mathrm{cx}$ \\
\hline & S4 & 6.83 & $16.80 \mathrm{~b}$ & 78.60ay & $57.84 b$ & 19.89by & 2.37 & $12.90 a$ & 3.55 & $3.45 c x$ & 2.91 by \\
\hline & S5 & 6.83 & $16.55 b$ & 80. & $54.94 c$ & Bby & 3.52 & 12 & 5 & $8 a x$ & 2.83 by \\
\hline \multirow{5}{*}{ High } & S1 & 6.83 & $5 a$ & 78. & 7c & & 3.07 & & & & $1 \mathrm{cz}$ \\
\hline & S2 & 6.83 & $17.52 a$ & $83.11 \mathrm{az}$ & $62.70 a$ & & 1.60 & & & dy & $3.41 \mathrm{az}$ \\
\hline & S3 & 6.83 & $17.51 a$ & $83.60 a z$ & $59.81 a$ & $17.82 \mathrm{cz}$ & 2.29 & & 3.43 & $3.24 c x$ & $3.36 a z$ \\
\hline & S4 & 6.83 & $15.89 \mathrm{~b}$ & $62.32 c x$ & $57.89 \mathrm{~b}$ & $17.75 \mathrm{cz}$ & 3.07 & $49 b$ & 4.61 & $9 a z$ & $3.29 a z$ \\
\hline & S5 & 6.83 & $15.70 \mathrm{~b}$ & $59.10 c x$ & $55.00 c$ & $17.67 \mathrm{cz}$ & 4.10 & $11.23 c$ & 6.17 & $3 a z$ & $3.11 a x$ \\
\hline $\mathrm{SEM}^{4}$ & & 0.007 & 0.184 & 0.184 & 0.061 & 0.319 & 0.234 & 0.313 & 0.028 & 0.290 & 0.007 \\
\hline \multicolumn{12}{|l|}{ P-values } \\
\hline SFO & & 0.987 & 0.273 & 0.027 & 0.285 & 0.034 & 0.051 & 0.060 & 0.067 & 0.033 & 0.044 \\
\hline PBP & & 0.953 & 0.025 & 0.001 & 0.041 & 0.029 & 0.050 & 0.031 & 0.082 & 0.005 & 0.001 \\
\hline $\mathrm{FO} \times \mathrm{PBP}$ & & 0.765 & 0.066 & $<0.001$ & 0.217 & 0.022 & 0.056 & 0.022 & 0.112 & 0.012 & 0.004 \\
\hline
\end{tabular}

${ }^{1}$ SFO, sunflower oil supplementation per incubation at no $(0 \mathrm{mg})$; low $(15 \mathrm{mg})$; high (30 mg); ${ }^{2}$ PBP, Piper betle L. powder supplementation per incubation at S1 (0 mg); S2 (15 mg); S3 (30 mg); S4 (45 mg); S5 (60 mg); ${ }^{3}$ dedicated as control treatment (only substrate); ${ }^{4} \mathrm{SEM}$, standard error of mean. Within a parameter as column, means with different superscript (a, b, c) differ at $p<0.05$ for the PBP effect in substrate; with different superscripts $(x, y, z)$ at $p<0.05$ for the SFO effect in substrate. 
total VFA in the present study might be due to the content of unsaturated fatty acids and carbohydrate sources in SFO and PBP, respectively. However, a previous meta-analysis reported that additional oil in a diet did not modulate rumen NDF degradability and displayed a negative effect, e.g. reducing dry matter intake (Weld; Armentano, 2017). It is worth noting that constituent nutrients of PBP may be more easily degraded than SFO by rumen inhabitants, thereafter boosting fermentation to produce more VFA (McSweeney et al., 2001). However, taken altogether, the present results were similar to prior studies both observed in vitro (Elghandour et al., 2017; Vargas et al., 2017) and in vivo (Atikah et al., 2018). Presumably, SFO might still affect the total volatile fermentation by modulating fiberdegrading bacteria in the rumen.

In the present study, SFO increased propionic acid, which was in agreement with a prior study (Vargas et al., 2017). However, PBP seemed to have the reverse effect on the propionate shift by systematically altering ruminal metabolism. This suggested that active plant compounds of PBP might have a broad effect on the breakdown in the activity of propionate-producing bacteria during nutrient metabolism via a propionate-generating pathway intermediate. Consequently, this deterioration amounted to less degradation of fermentable cellulose, which was concomitant of a reduced propionic fraction. A lower propionic number may be linked to a lower concentration of valeric acid as well (Andries et al., 1987).

Furthermore, our results addressed the greater concentrations of acetic and butyric acids that may have occurred because of the quercetin and eugenol in PBP. However, these findings contradicted prior studies (Castillejos; Calsamiglia; Ferret, 2006; Oskoueian; Abdullah; Oskoueian, 2013). A possible reason for these different outcomes could be to the interaction between the basal substrate used and the available plant secondary metabolite. For example, Oskoueian, Abdullah and Oskoueian (2013) and Castillejos, Calsamiglia and Ferret (2006) fed the fermenters a 60:40 forage: concentrate diet, whereas in our study, a 50:50 Pangola hay: concentrate diet was used. In addition, those reports used a commercial extract to obtain quercetin and eugenol. These differences in concentrations of acetic and butyric acids could be due to the varied molecular weight content of the plant secondary metabolite used. Hence, response-dependent purity has been suggested to affect substrate fermentation (Petlum; Paengkoum; Liang, 2019). In the present study, organic compounds such as quercetin and eugenol might still bind other natural compounds such as phenolic acids (Purba; Paengkoum 2019). Therefore, quercetin and eugenol still allowed ruminal microorganisms to produce a wide extent of acetic and butyric fractions.

Supplementation of PBP decreased ammonia deposition in the present study. PBP seemed to affect the deamination process through an ammonia-inhibiting feature exhibiting slow affinity due to high amounts of PBP (at least $45-50 \mathrm{mg}$ ) supplementations. This result was consistent with other studies involving dietary quercetin (Oskoueian; Abdullah; Oskoueian, 2013) and eugenol (Castillejos; Calsamiglia; Ferret, 2006). Given those references, the reduction in ammonia might be due to eugenol. Eugenol seemed to have stronger antimicrobial properties compared to the other secondary metabolites in inhibiting protein degradability in the rumen (Castillejos; Calsamiglia; Ferret, 2006). Eugenol supplementation dosed to at least $50 \mathrm{mg} \mathrm{L}^{-1}$ in the fermenter decreased the ammonia concentration without changing the $\mathrm{pH}$ (Castillejos; Calsamiglia; Ferret, 2006). In the present study, the ranges of ammonia concentration and $\mathrm{pH}$ were $15.7-18.0 \mathrm{mg} 100 \mathrm{~mL}^{-1}$ and $6.8-6.9$, respectively, which represented the acceptable conditions for ruminal microorganisms to survive for modulating microbial growth and fermentation efficiency (Ørskov; MacLeod, 1982).

\section{Microbial composition}

Total bacteria were similar among the treatments (Table 4). Significant effects $(p<0.05)$ of SFO $\times$ PBP were observed for rumen protozoa and fungal zoospores $(p<0.01)$. It has been reported that a change of ruminal biogases and fermentation end-products in the rumen might indicate a shift in the ruminal microorganisms (Ungerfeld; Aedo; Martínez, 2019). In the present study, SFO and PBP disturbed ruminal protozoa activity and suppressed ruminal protozoa numbers. It has been previously reported that plants richer in polyphenols, especially tannins, flavonoids, and essential oils, reduced the protozoa community in rumens (Castillejos; Calsamiglia; Ferret, 2006; Oskoueian; Abdullah; Oskoueian, 2013; Cherdthong et al., 2019). In the present study, flavonoids and essential oils present in PBP, either with or without SFO, seemed to have a wider antimicrobial effect, leading to direct deteriorations of protozoa by undertaking cell wall synthesis or nucleic acid synthesis (Cherdthong et al., 2019). Moreover, the decrease in the protozoa did not affect the total number of rumen bacteria. Among flavonoids and essential oils in PBP, quercetin was the predominant active compound (Table 1). This might relate to an earlier report which indicated that supplementing flavonoids like quercetin did not vary the total bacteria in the rumen (Oskoueian; 
Abdullah; Oskoueian, 2013). Quercetin has been suggested to have control in maintaining cellulolytic bacteria with lower protozoa and methanogen populations. Although, a possible reason for the escalated fungal zoospores may be related to the altered number of rumen protozoa. Newbold et al. (2015) reported that fungal zoospores slightly increased with a slightly decreased protozoal number, which reflected small competition between fungal zoospores and protozoa regarding consumption of the substrate during fermentation. To support this assessment, fungal zoospores have been reported to have

Table 4: Effect of treatments on ruminal microorganism.

\begin{tabular}{|c|c|c|c|c|}
\hline \multirow[b]{2}{*}{$\mathrm{SFO}^{1}$} & \multirow[b]{2}{*}{$\mathrm{PBP}^{2}$} & \multicolumn{3}{|c|}{ Ruminal microbes (cells $\mathrm{mL}^{-1}$ ) } \\
\hline & & $\begin{array}{c}\text { Total } \\
\text { bacteria } \\
\left(\times 10^{7}\right)\end{array}$ & $\begin{array}{c}\text { Total } \\
\text { protozoal } \\
\left(\times 10^{5}\right)\end{array}$ & $\begin{array}{c}\text { Total fungal } \\
\text { zoospore } \\
\left(\times 10^{5}\right)\end{array}$ \\
\hline \multirow{5}{*}{ No } & $\mathrm{S} 1^{3}$ & $6.15 x$ & $4.78 a x$ & $2.93 c x$ \\
\hline & S2 & $6.14 x$ & $4.50 a x$ & $3.06 c x$ \\
\hline & S3 & $6.12 x$ & $4.21 \mathrm{bx}$ & $3.10 b x$ \\
\hline & S4 & $6.10 x$ & $3.98 b x$ & $3.14 b x$ \\
\hline & S5 & $6.08 x$ & $3.74 c x$ & $3.21 a x$ \\
\hline \multirow{5}{*}{ Low } & S1 & $8.20 y$ & 4.19ay & 3.15by \\
\hline & S2 & $7.28 y$ & 3.93by & 3.25by \\
\hline & S3 & $7.10 y$ & 3.69by & 3.38ay \\
\hline & S4 & $7.26 y$ & 3.47cy & 3.44ay \\
\hline & S5 & $8.15 y$ & $3.24 c z$ & 3.56ay \\
\hline \multirow{5}{*}{ High } & S1 & $9.30 z$ & $3.71 \mathrm{az}$ & $3.66 \mathrm{bz}$ \\
\hline & S2 & $9.18 z$ & $3.34 c z$ & $3.88 \mathrm{bz}$ \\
\hline & S3 & $8.89 z$ & $3.27 c z$ & $4.12 \mathrm{az}$ \\
\hline & S4 & $8.95 z$ & $3.08 \mathrm{dz}$ & $4.40 a z$ \\
\hline & S5 & $9.58 z$ & $2.89 \mathrm{ez}$ & 4.69az \\
\hline $\mathrm{SEM}^{4}$ & & 0.344 & 0.139 & 0.141 \\
\hline \multicolumn{5}{|l|}{ P-values } \\
\hline SFO & & 0.016 & 0.037 & 0.030 \\
\hline PBP & & 0.092 & 0.001 & 0.022 \\
\hline $\mathrm{SFO} \times \mathrm{PBP}$ & & 0.051 & 0.002 & 0.007 \\
\hline
\end{tabular}

${ }^{1} \mathrm{SFO}$, sunflower oil supplementation per incubation at no $(0$ $\mathrm{mg})$; low (15 mg); high (30 mg); ${ }^{2} \mathrm{PBP}$, Piper betle L. powder supplementation per incubation at S1 (0 mg); S2 (15 mg); S3 (30 mg); S4 (45 mg); S5 (60 mg); ${ }^{3}$ dedicated as control treatment (only substrate); ${ }^{4}$ SEM, standard error of mean. Within a parameter as column, means with different superscript $(a, b, c)$ differ at $p<0.05$ for the PBP effect in substrate; with different superscripts $(x, y, z)$ at $p<0.05$ for the SFO effect in substrate. a strong defense towards interruption by plant-containing polyphenols (Cherdthong et al., 2019). Therefore, fungal zoospores could be assessed as the remaining microorganisms that ingest the ruminal substrate during fermentation.

\section{CONCLUSIONS}

This study suggested that flavonoids and their aromatic derivatives obtained from the edible plant Piper betle L. dosed at 15-30 mg per incubation on a dry matter basis promotes in vitro methane mitigation while improving rumen fermentation. Incorporating Piper betle powder with sunflower oil as a dietary fat also showed a positive interaction. These findings might be useful for application in ruminant diets, as they are expected to reduce the existential greenhouse gas emissions from livestock. Furthermore, providing Piper betle powder could contribute to limiting agricultural waste.

\section{ACKNOWLEDGEMENTS}

The authors thank to Nurrahim Dwi Saputra, Aliyatur Rosyidah and all staffs of the center of scientific and technological equipment (CSTE), Suranaree University of Technology for their helps in laboratory and farm. This work was supported by Suranaree University of Technology (SUT) and Office of the Higher Education Commission under NRU Project of Thailand.

\section{REFERENCES}

ANDRIES, J. I. et al. Isoacids in ruminant nutrition: Their role in ruminal and intermediary metabolism and possible influences on performances - A review. Animal Feed Science and Technology, 18(3):169-180, 1987.

AOAC. Official methods of analysis. AOAC International Suite 500: Gaitherburg, Maryland, USA, 2005. 72p.

ATIKAH, I. N. et al. Profiling of rumen fermentation, microbial population and digestibility in goats fed with dietary oils containing different fatty acids. BMC Veterinary Research, 4(1):344, 2018.

CANOVA, É. B. et al. Crambe cake (Crambe abyssinica Hochst) on lamb diets. Ciência e Agrotecnologia, 39(1):75-81, 2015.

CASTILLEJOS, L.; CALSAMIGLIA, S.; FERRET, A. Effect of essential oil active compounds on rumen microbial fermentation and nutrient flow in in vitro systems. Journal of Dairy Science, 89(7):2649-2658, 2006. 
CHERDTHONG, A. et al. Effects of supplementation of Piper sarmentosum leaf powder on feed efficiency, rumen ecology and rumen protozoal concentration in Thai native beef cattle. Animals, 9(4):130, 2019.

ELGHANDOUR, M. M. Y. et al. Effects of Schizochytrium microalgae and sunflower oil as sources of unsaturated fatty acids for the sustainable mitigation of ruminal biogases methane and carbon dioxide. Journal of Cleaner Production, 168(1):1389-1397, 2017.

ERWIN, E. S.; MARCO, G. J.; EMERY, E. M. Volatile fatty acid analyses of blood and rumen fluid by gas chromatography. Journal of Dairy Science, 44(9):1768-1771, 1961.

GALYEAN, M. Laboratory procedure in animal nutrition research. Department of Animal and Life Science: New Mexico State University, Las Cruces, 1989. 122p.

GUHA, P. Betel leaf: The neglected green gold of India. Journal of Human Ecology, 19(2): 87-93, 2006.

HAOUJAR, I.; CACCIOLA, F.; ABRINI, J. et al. The contribution of carotenoids, phenolic compounds, and flavonoids to the antioxidative properties of marine microalgae isolated from Mediterranean Morocco. Molecules, 24(22): 4037, 2019.

HOOK, S. E.; WRIGHT, A. D. G.; MCBRIDE, B. W. Methanogens: Methane producers of the rumen and mitigation strategies. Archaea, 2010(945785):1-11, 2010.

JAYANEGARA, A.; LEIBER, F.; KREUZER, M. Meta-analysis of the relationship between dietary tannin level and methane formation in ruminants from in vivo and in vitro experiments. Journal of Animal Physiology and Animal Nutrition, 96(3): 365-375, 2012.

KAPS, M.; LAMBERSON, W. R. Biostatistics for Animal Science. CABI: Oxfordshire, UK, 2004. 459p.

LOURENÇO, M. et al. Effects of saponins, quercetin, eugenol, and cinnamaldehyde on fatty acid biohydrogenation of forage polyunsaturated fatty acids in dual-flow continuous culture fermenters. Journal of Animal Science, 86(11):3045-3053, 2014.

MANDALARI, G. et al. Antimicrobial activity of flavonoids extracted from bergamot (Citrus bergamia Risso) peel, a byproduct of the essential oil industry. Journal of Applied Microbiology, 103(6):2056-2064, 2007.

MCSWEENEY, C. S. et al. Microbial interactions with tannins: Nutritional consequences for ruminants. Animal Feed Science and Technology, 91(1/2):8393, 2001.
MENKE, K. H.; STEINGASS, H. Estimation of the energetic feed value obtained from chemical analysis and in vitro gas production using rumen fluid. Animal Research and Development, 28(2):7-55, 1988.

NEWBOLD, C. J. et al. The role of ciliate protozoa in the rumen. Frontiers in Microbiology, 6(2015):1313-1313, 2015.

ØRSKOV, E.; MACLEOD, N. The determination of the minimal nitrogen excretion in steers and dairy cows and its physiological and practical implications. British Journal of Nutrition, 47(3):625-636, 1982.

ORSKOV, E. R.; MCDONALD, I. The estimation of protein degradability in the rumen from incubation measurements weighted according to rate of passage. The Journal of Agricultural Science, 92(2):499-503, 1970.

OSKOUEIAN, E.; ABDULLAH, N.; OSKOUEIAN, A. Effects of flavonoids on rumen fermentation activity, methane production, and microbial population. BioMed Research International, 2013(349129):1-8, 2013.

PATRA, A. K.; SAXENA, J. A new perspective on the use of plant secondary metabolites to inhibit methanogenesis in the rumen. Phytochemistry, 71(11-12):1198-1222, 2010.

PATRA, A. K.; YU, Z. Effective reduction of enteric methane production by a combination of nitrate and saponin without adverse effect on feed degradability, fermentation, or bacterial and archaeal communities of the rumen. Bioresource and Technology, 148(352-360, 2013.

PATRA, A. K.; YU, Z. Effects of adaptation of in vitro rumen culture to garlic oil, nitrate, and saponin and their combinations on methanogenesis, fermentation, and abundances and diversity of microbial populations. Frontiers in Microbiology, 6(1434):2015.

PETLUM, A.; PAENGKOUM, P.; LIANG, J. B. et al. Molecular weight of condensed tannins of some tropical feed-leaves and their effect on in vitro gas and methane production. Animal Production Science, 59(12):2154-2160, 2019.

PURBA, R. A. P.; PAENGKOUM, P. Bioanalytical HPLC method of Piper betle L. for quantifying phenolic compound, watersoluble vitamin, and essential oil in five different solvent extracts. Journal of Applied Pharmaceutical Science, 9(5):33-39, 2019

PURBA, R. A. P.; PAENGKOUM, P.; PAENGKOUM, S. The links between supplementary tannin levels and conjugated linoleic acid (CLA) formation in ruminants: A systematic review and meta-analysis. PLOS ONE, 5(3):e0216187, 2020. 
PURBA, R. A. P.; YUANGKLANG, C.; PAENGKOUM, P. Enhanced conjugated linoleic acid and biogas production after ruminal fermentation with Piper betle L. supplementation. Ciência Rural, 50(7):e20191001, 2020.

RIBEIRO JUNIOR, G. O. et al. Production, nutritional quality and in vitro methane production from Andropogon gayanus grass harvested at different maturities and preserved as hay or silage. Asian-Australasian Journal of Animal Sciences, 27(3):330-341, 2014.

SEJIAN, V. et al. Modeling of greenhouse gas emissions in dairy farms. Journal of Animal Science Advances, 1(1):12-20, 2011.

THEODOROU, M. K. et al. A simple gas production method using a pressure transducer to determine the fermentation kinetics of ruminant feeds. Animal Feed Science and Technology, 48(3):185-197, 1994.

TIAN, X. Z. et al. Effects of anthocyanin-rich purple corn (Zea mays L.) stover silage on nutrient utilization, rumen fermentation, plasma antioxidant capacity, and mammary gland gene expression in dairy goats. Journal of Animal Science, 97(3):1384-1397, 2018.

TILLEY, J. M. A.; TERRY, R. A. A two-stage technique for the in vitro digestion of forage crops. Grass and Forage Science, 18(2):104-111, 1963.

ULTEE, A.; BENNIK, M. H. J.; MOEZELAAR, R. The phenolic hydroxyl group of carvacrol is essential for action against the food-borne pathogen Bacillus cereus. Applied and Environmental Microbiology, 68(4):1561-1568, 2002.

UNGERFELD, E. M.; AEDO, M. F.; MARTÍNEZ, E. D. et al. Inhibiting methanogenesis in rumen batch cultures did not increase the recovery of metabolic hydrogen in microbial amino acids. Microorganisms, 7(5):115, 2019.

VAN SOEST, P. J.; ROBERTSON, J. B.; LEWIS, B. A. Methods for dietary fiber, neutral detergentfiber, andnonstarch polysaccharides in relation to animal nutrition. Journal of Dairy Science, 74(91):3583-3597, 1991.

VARGAS, J. E. et al. Effect of sunflower and marine oils on ruminal microbiota, in vitro fermentation and digesta fatty acid profile. Frontiers in Microbiology, 8(2017):11241124, 2017.

VASTA, V.; DAGHIO, M.; CAPPUCCI, A. et al. Invited review: Plant polyphenols and rumen microbiota responsible for fatty acid biohydrogenation, fiber digestion, and methane emission: Experimental evidence and methodological approaches Journal of Dairy Science, 102(5): 3781-3804, 2019.

WAGHORN, G. C.; MCNABB, W. C. Consequences of plant phenolic compounds for productivity and health of ruminants. Proceedings of the Nutrition Society, 62(2): 383-392, 2003.

WELD, K. A.; ARMENTANO, L. E. The effects of adding fat to diets of lactating dairy cows on total-tract neutral detergent fiber digestibility: A meta-analysis. Journal of Dairy Science, 100(3):1766-1779, 2017.

WOLIN, M. J. The rumen fermentation: A model for microbial interactions in anaerobic ecosystems. In: ALEXANDER, M. Advances in Microbial Ecology. Boston: Springer US, 1979. v.3, p.49-77.

YANZA, Y. R. et al. Coleus amboinicus (Lour.) leaves as a modulator of ruminal methanogenesis and biohydrogenation in vitro. Journal of Animal Science, 96(11):4868-4881, 2018. 